\title{
The Effect of Fermented Aflatoxins Contaminated Feed on Digestibility and Performance of Broiler Chickens
}

\author{
Mukandungutse B Isabelle ${ }^{1 *}$, James K Tuitoek ${ }^{1}$, Anthony M King'ori ${ }^{1}$, and Meshack A Obonyo ${ }^{2}$ \\ ${ }^{1}$ Department of Animal Science, Egerton University, P O Box 536 - 20115, Egerton, Kenya \\ ${ }^{2}$ Department of Biochemistry\& Molecular Biology, Egerton University, P O Box 536 - 20115, Egerton, Kenya \\ *corresponding author e-mail: muisabetty@gmail.com
}

\begin{abstract}
Broiler chicken farming is a major sector of the poultry industry. Poultry is susceptible to mycotoxicoses caused by aflatoxins. The experiment was carried out, where 144 DOCs were allocated to six diets. The diets were diet1 (no aflatoxin and not fermented), diet2 (no aflatoxin and fermented without yeast), diet3 (no aflatoxin and fermented with yeast), diet4 (contained aflatoxin and not fermented), diet5 (contained aflatoxin and fermented without yeast) and diet6 (contained aflatoxin fermented with yeast). The aflatoxin level was $30.08 \mathrm{ppb}$. Each diet was assigned to 6 chicks, replicated 4 times for 21 days. Leftovers and mortalities were recorded daily and chicks were weighed on a weekly basis. Feed consumption and body weight gain were not different across treatments. However, gain to feed ratio was significantly $(p=0.048)$ better in broilers fed diets fermented naturally. The mortality rate was $75.0 \%$ in chicks fed on a non-fermented aflatoxin diet. Therefore, natural fermentation is the best method of improving the quality of aflatoxin contaminated feed for broilers.
\end{abstract}

Keywords: aflatoxin, broiler chicken, fermentation, mycotoxins, poultry

Abstrak. Peternakan ayam broiler adalah sektor utama industri perunggasan. Unggas rentan terhadap mikotoksikosis yang disebabkan oleh aflatoksin. Percobaan dilakukan menggunakan 144 ayam broiler berumur satu hari yang diberi pakan enam jenis pakan. Pakan tersebut adalah P1 (tanpa aflatoksin dan tidak difermentasi), P2 (tanpa aflatoksin dan difermentasi tanpa ragi), P3 (tanpa aflatoksin dan difermentasi dengan ragi), P4 (mengandung aflatoksin dan tidak difermentasi), P5 (mengandung aflatoksin dan difermentasi tanpa ragi) dan P6 (mengandung aflatoksin yang difermentasi dengan ragi). Tingkat aflatoksin yang digunakan adalah 30,08 ppb. Setiap jenis pakan diberikan untuk 6 ekor anak ayam dan diulang 4 kali selama 21 hari. Sisa pakan dan kematian dicatat setiap hari dan anak-anak ayam ditimbang setiap minggu. Tidak ada perbedaan yang ditemukan dalam asupan pakan dan pertambahan bobot badan. Namun demikian rasio pertambahan terhadap rasio pakan menunjukkan perbedaan secara nyata $(p=0,048)$ lebih baik dibandingkan dengan ayam broiler yang diberi pakan fermentasi secara alami. Tingkat kematian adalah $75,0 \%$ pada anak ayam yang diberi pakan aflatoksin non-fermentasi. Oleh karena itu, fermentasi alami adalah metode terbaik untuk meningkatkan kualitas pakan yang terkontaminasi aflatoksin untuk ayam pedaging.

Kata kunci: aflatoksin, ayam broiler, fermentasi, mikotoksin, unggas

\section{Introduction}

The consumption of poultry meat keeps growing across the globe in both first and third world countries (Kralik et al., 2018). Broiler chicken farming is a major sector of the poultry industry. Additionally, chicken meat is a high biological value protein (Da Silva et al., 2017) and a nutritious diet since it contains moderate energy (Marangoni et al., 2015). Having a lower fat content and higher PUFA than other meats, poultry meat is the recommended item in a balanced diet. (Riovanto et al., 2012). The quality of feed may be compromized when it is exposed to any contamination (bacterial, fungal, and mold) during storage; consequently, the feed is spoilt and the poultry is more likely to get infected (Sugiharto and Ranjitkar, 2018). For example, broilers carrying aflatoxin B1 could make the economy and public health suffer tremendously (Yunus et al., 2011). The negative effect of aflatoxin to birds is most significant in production aspects, such as weight gain, feed consumption, feed conversion ratio (FCR) and harvest (Hussain et al., 2010). Aflatoxins were 
discovered in 1960 and are widely associated with maize, groundnuts, tree nuts, figs, dates and oil seeds, such as cotton seeds (Kanyi, 2018; Negash, 2018). Aflatoxin B1, B2, G1 and G2 are the most prevalent toxins to interfere with metabolism of carbohydrates, fats and nucleic acids in livestock (Negash, 2018). In maize, the most vigorous aflatoxin (Aflatoxin B1) is produced from an abundant amount of $A$. flavus and parasiticus (Zaki et al., 2012).

According to many regulatory bodies on aflatoxins, the tolerable levels of total aflatoxins in foodstuffs and animal feeds are different. The World Health Organization (WHO) set aflatoxins limits of 5ppb for animals (Kajuna et al., 2013), while the United States Food and Drug Administration and European Commission set $20 \mathrm{ppb}$ as the maximum tolerable level of total aflatoxins for poultry feed (Syahidah et al., 2017). The concentrations of AFB1 in poultry meat and the edible parts may be elevated irrespective of whether the aflatoxin levels in the diet is low (22ppb) or high (2500ppb) (Fouad et al., 2019). Fermenting the feed could lower the non-nutritive substance, increase the overall nutritive value of the feed (Aljuobori et al., 2014; Çabuk et al., 2018) and reduce total aflatoxin levels (Mukandungutse et al., 2019). Additionally, digestive tract (crop and gizzard) may contain less Campylobacter and Salmonella due to consuming fermented feed. (Jawad et al., 2016). Sugiharto et al. (2015) reported that grain fraction (not complete feed), which is fermented prior to mixing with compound feed may help avoid losing some essential nutrients in fermented feeds. The use of fermented liquid feed appears to be a cost-effective alternative to the use of antibiotics growth promoters (Missotten et al., 2013). This study evaluated the effect of fermented contaminated feed with aflatoxins on the digestibility and performance of broiler chickens.

\section{Materials and Methods}

\section{Source of aflatoxin}

Clean (tested, aflatoxin-free) maize kernels were inoculated with Aspergillus flavus obtained from contaminated samples of maize. The incubation of maize $\left(31^{\circ} \mathrm{C}, 60\right.$ days) was conducted while retaining the moisture intermittently to allow fungi to grow well and aflatoxin to produce. ELSA technique was performed to obtain AF level following manufacturer's instructions.

\section{Fermentation}

After inoculation, the contaminated maize and clean maize was milled using a sieve of $0.8 \mathrm{~mm}$ into flour from which the water was added to the maize flour in the ratio of $1: 1.5 \mathrm{w} / \mathrm{v}$ (weight of maize flour/volume of water). The fermentation was done either without or by adding Saccharomyces cerevisiae (NCYC 125) at room temperature $\left(25^{\circ} \mathrm{C}\right)$ for 72 hours, then sun dried. After drying, fermented maize flour was used to compound six experimental diets.

\section{Experimental diets, animals, design and treatments}

A total of 144 DOC (broilers) were purchased from a commercial breeding place (Kenchic). All vaccination procedures against Gumboro and New Castle diseases were carried out by the hatchery before supply. The chicks were then put in a room which was well ventilated and fitted with fluorescent lighting. It was cleaned with liquid soap and disinfected before occupation by the chicks. The chicks were weighed individually before feeding. During brooding, the room was warmed to $30-34^{\circ} \mathrm{C}$ using infrared bulbs and there was continuous lighting. In the poultry house, 24 partitions, with $1.2 \times 1.2 \mathrm{~m}$ each, were made. Each diet was assigned to 6 broiler chickens of similar body weights and replicated four times. Chickens were offered the six diets for 21 days. The six 
experimental diets were offered in clean disinfected feeders daily at 09:00hrs. The leftover feed was collected, weighed, recorded and fresh feed provided before the next feeding. The broilers were given clean, ad libitum drinking water. The diet composition was based on NRC standard (1994) for starter broilers (23\% crude protein and about $3200 \mathrm{Kcal} / \mathrm{kg}$ metabolizable energy). The experimental design was a "three by two factorial" arrangement where factor one was the type of fermentation (not fermented, fermented without yeast and fermented with yeast) and factor two was aflatoxin ( 0 and $30.08 \mathrm{ppb}$ ). The six experimental diets are shown on Table 1. Every morning at 09:00hrs, the leftover feed was collected, weighed, and recorded before providing fresh feed. Daily feed consumption was calculated as total feed offered minus total leftover. The chicks were weighed once every week before feeding. Body weight gain (BWG) and average daily gain (ADG) of each chicken were calculated. BWG is the score after subtracting final weight by the initial weight, while ADG is BWG divided by seven days. Gain to Feed ratio (the total feed needed to gain one unit of weight) was obtained by dividing (ADG) by (ADFI).

All data were analyzed using an analysis of variance (ANOVA) in the General linear model (GLM) of Statistical Analysis Systems (SAS, 2009) software. An F-test at 5\% probability level was employed to test for significance and means separation was done by Least Significant Difference Procedure

Table 1. Composition of experimental diets

\begin{tabular}{|c|c|c|c|c|c|c|}
\hline Ingredients (g/100g) & Diet 1 & Diet 2 & Diet 3 & Diet 4 & Diet 5 & Diet 6 \\
\hline Maize & 69 & 69 & 69 & 69 & 69 & 69 \\
\hline Soy Bean Meal & 6 & 6 & 6 & 6 & 6 & 6 \\
\hline Omena $^{1}$ & 23 & 23 & 23 & 23 & 23 & 23 \\
\hline Dicalcium-Phosphate & 1 & 1 & 1 & 1 & 1 & 1 \\
\hline Limestone & 0.25 & 0.25 & 0.25 & 0.25 & 0.25 & 0.25 \\
\hline lodized salt & 0.25 & 0.25 & 0.25 & 0.25 & 0.25 & 0.25 \\
\hline Mineral and Vitamin Premix ${ }^{2}$ & 0.5 & 0.5 & 0.5 & 0.5 & 0.5 & 0.5 \\
\hline Total & 100 & 100 & 100 & 100 & 100 & 100 \\
\hline Calculated ME (Kcal/kg) & 3076 & 3076 & 3076 & 3076 & 3076 & 3076 \\
\hline Calculated CP (\%) & 22.6 & 22.6 & 22.6 & 22.6 & 22.6 & 22.6 \\
\hline Calculated AF in diet (ppb) & 0 & 0 & 0 & 30.08 & 30.08 & 30.08 \\
\hline
\end{tabular}

${ }^{1}$ Scientific name: Rastrineobola Argentea, common name; silver cyprinid, and it has also been called the Lake Victoria sardine or mukene.

${ }^{2}$ Supplied the following per Kg of diet: Vit. $A=10,000 \mathrm{IU}$; Vit. $D=2,800 \mathrm{IU}$; Vit. $\mathrm{E}=24 \mathrm{mg}$; Vit. $\mathrm{K}=2 \mathrm{mg}$; Vit. $\mathrm{B} 1=1 \mathrm{mg}$; Vit. B2 = 4mg; Vit. B6 = 4mg; Vit. B12 =16mg, Vit. C = 200mg; Niacin =10mg; Folic acid =1.6mg; Biotin=60mg; $\mathrm{Mn}=80 \mathrm{mg} ; \mathrm{Fe}=25 \mathrm{mg}$; $\mathrm{Cu}=5 \mathrm{mg} ; \mathrm{Zn}=50 \mathrm{mg} ; \mathrm{Se}=200 \mathrm{mg}$ and $\mathrm{KI}=1.2 \mathrm{mg}$.

Diet 1 (no aflatoxin and not fermented), Diet 2 (no aflatoxin and fermented without yeast), Diet 3 (no aflatoxin and fermented with yeast), Diet 4 (contained aflatoxin and not fermented), Diet 5 (contained aflatoxin and fermented without yeast) and Diet 6 (contained aflatoxin fermented with yeast).

\section{Results and Discussion}

The feed intake of the non-contaminated and contaminated diets was not improved by fermentation. Fermentation without yeast and fermentation with yeast had similar effects on feed intake whether diet is contaminated or not. The fermentation types did not significantly affect the feed consumption and body weight gain. The gain to feed ratio of chicken had been affected by fermentation types with $p$ - 
value $=0.048$. The total aflatoxin levels had no significant effect on the chickens' performance.

Table 2. The effect of fermentation and aflatoxins on feed intake $(\mathrm{g} / \mathrm{d})$, body weight gain $(\mathrm{g} / \mathrm{d})$ and gain: feed ratio of broiler chickens

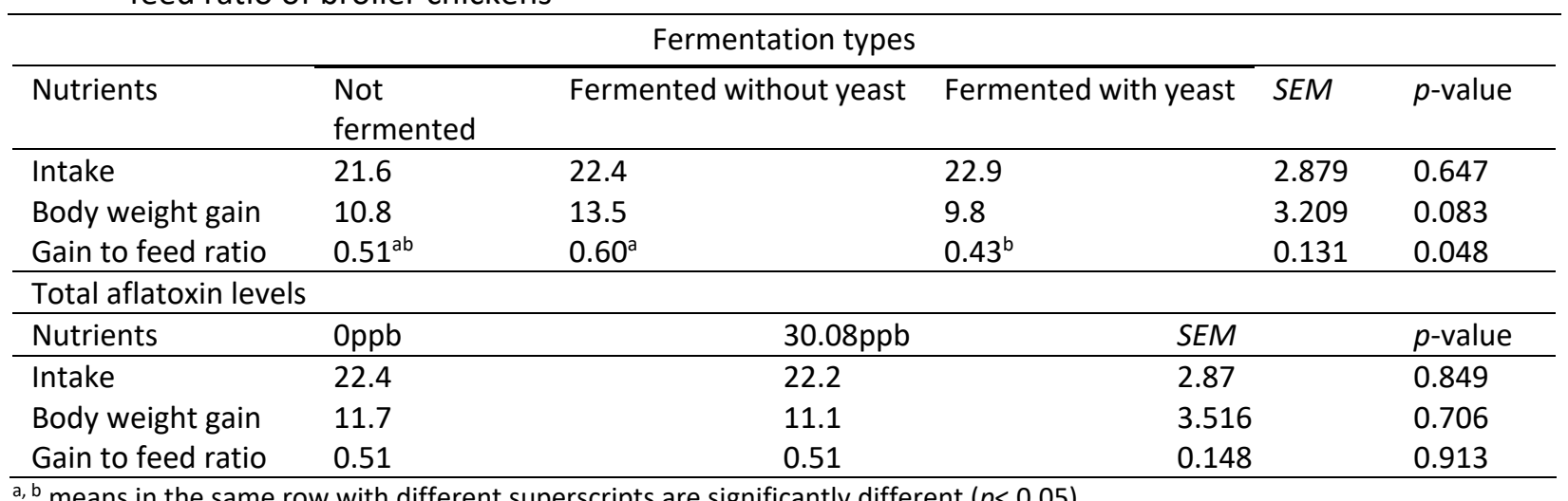

Table 3. Dietary effect on mortality rate of broiler chickens at 21 days

\begin{tabular}{llll}
\hline Diet & Number of chicks per diet & Number of dead chicks & Mortality rate (\%) \\
\hline Diet 1 & 24 & 1 & 4.2 \\
Diet 2 & 24 & 3 & 12.5 \\
Diet 3 & 24 & 4 & 16.7 \\
Diet 4 & 24 & 18 & 75.0 \\
Diet 5 & 24 & 7 & 29.2 \\
Diet 6 & 24 & 14 & 58.3 \\
\hline
\end{tabular}

Diet 1: No aflatoxin and not fermented, Diet 2: No aflatoxin and fermented without yeast, Diet 3: No aflatoxin and fermented with yeast, Diet 4: Contained 30.08ppb aflatoxin and not fermented, Diet 5: Contained 30.08ppb aflatoxin and fermented without yeast, Diet 6: Contained 30.08ppb aflatoxin fermented with yeast.

The feed intake, body weight gain and gain to feed ratio were not significantly $(p>0.05)$ different within the six diets (Table2). The types of fermentation did not improve feed consumption and body weight gain during 21days of study, but improved the gain to feed ratio (Table2). The study done by Naji et al. (2016) indicated that fermented feed with probiotics was economically beneficial since it improved broiler feed conversion ratio. Broiler chickens fed on fermented moist feed showed a detrimental effect on early bird growth but affected beneficially feed efficiency (Missotten et al., 2013). Pre-arranged probiotics for wet fermented feed may cause a significant improvement in chicken feed conversion ratio (Jawad et al., 2016). The total aflatoxin level of $30.08 \mathrm{ppb}$ did not significantly affect intake, body weight gain and feed conversion ratio (Table2). Many studies reported decreased feed consumption and body weight gain as well as an increased feed conversion ratio when higher levels of aflatoxin were used in the feed (Table 4).

The mortality rate was $75.0 \%$ (Table 3 ) in the non-fermented feed with $30.08 \mathrm{ppb}$ total aflatoxin levels which was greater than the United States Food and Drug Administration (USFDA) and European Union Commission (EUC) maximum tolerable limit of 20ppb (Morrison et al., 2017). Sobrane et al. (2016) observed the $20.13 \% \pm 9.45$ mortality rate of broilers fed contaminated feed with 2000ppb aflatoxin B1. During this study, some of the chicks fed on aflatoxins-contaminated feed were not able to stand on their feet. 
Table 4. Summary of the effects of aflatoxin levels in broiler feed and their effects on body weight, feed intake and feed conversion ratio

\begin{tabular}{|c|c|c|}
\hline $\begin{array}{l}\text { Aflatoxin levels in the } \\
\text { feed }\end{array}$ & Effects on body weight gain, feed intake and FCR & References \\
\hline $\begin{array}{l}\text { 700, } 1700 \text { and } 2800 p p b \\
\text { AFs }\end{array}$ & Lowered body weight, depressed feed intake, increased FCR & $\begin{array}{l}\text { (Marchioro et al., } \\
\text { 2013) }\end{array}$ \\
\hline 1500ppb AFB1 & Impaired growth & (Chen et al., 2016) \\
\hline 1000ppb AFB1 & Lowered growth rate & $\begin{array}{l}\text { (Ali Rajput et al., } \\
\text { 2017) }\end{array}$ \\
\hline $\begin{array}{l}\text { 200ppb and 400ppb } \\
\text { AFs }\end{array}$ & $\begin{array}{l}\text { Reduced body weight, daily weight gain, feed intake and } \\
\text { increased FCR }\end{array}$ & $\begin{array}{l}\text { (Valchev et al., } \\
\text { 2017) }\end{array}$ \\
\hline
\end{tabular}

\section{Conclusions}

Fermentation with or without yeast did not affect feed intake and body weight gain but improved gain to feed ratio of broiler chickens. The mortality rate was high $(75.0 \%)$ in nonfermented feed containing 30.08ppb aflatoxin.

\section{Acknowledgements}

The authors would like to thank the Center of Excellence in Sustainable Agriculture and Agribusiness Management (CESAAM) of Egerton University and National Research Fund of Kenya (NRF-Kenya), for financially supporting this study.

\section{References}

Ali, R.S., L. Sun, N. Zhang, M.M. Khalil, X. Gao, Z. Ling, L. Zhu, F. Khan, J. Zhang, and D. Qi. 2017. Ameliorative effects of grape seed proanthocyanidin extract on growth performance, immune function, antioxidant capacity, biochemical constituents, liver histopathology and aflatoxin residues in broilers exposed to aflatoxin B1. Toxins. 9(11): 371.

Aljuobori, A., Z. Idrus, S.F. Abdoreza, A. Norhani, J.B. Liang, and E.A. Awad. 2014. Effect of solid state fermentation on nutrient content and ileal amino acids digestibility of canola meal in broiler chickens. Ital. J. Anim. Sci. 13(2): 410-414.

Çabuk, B., M.G. Nosworthy, A.K. Stone, D.R. Korber, T. Tanaka, J.D. House, and M.T. Nickerson. 2018. Effect of fermentation on the protein digestibility and levels of non-nutritive compounds of pea protein concentrate. Food Technol. Biotechnol. 56(2): 257-264.

Chen, X., R. Murdoch, Q. Zhang, D.J. Shafer, and T.J. Applegate. 2016. Effects of dietary protein concentration on performance and nutrient digestibility in Pekin ducks during aflatoxicosis. Poult. Sci. 95(4): 834-841.

Da Silva, D.C.F., A.M.V. de Arruda, and A.A. Gonçalves. 2017. Quality characteristics of broiler chicken meat from free-range and industrial poultry systems for the consumers. Food Sci. Technol. 54(7): 1818-1826.

Fouad, A.M., D. Ruan, H.K. El-Senousey, W. Chen, S. Jiang, and C. Zheng. 2019. Harmful Effects and Control Strategies of Aflatoxin B1 Produced by Aspergillus flavus and Aspergillus parasiticus Strains on Poultry. Toxins. 11(3): 1-21.

Hussain, Z., M.Z. Khan, A. Khan, I. Javed, M.K. Saleemi, S. Mahmood, and M.R. Asi. 2010. Residues of aflatoxin B1 in broiler meat: Effect of age and dietary aflatoxin B1 levels. Food Chem. Toxicol. 48(12): 3304-3307.

Jawad, H.S., I.H. Lokman, S.A. Naji, A.B.Z. Zuki, and A.B. Kassim. 2016. Effects of dietary supplementation of wet fermented feed with probiotics on the production performance of Akar Putra chicken. Asian J. Poult. Sci. 10(2): 72-77.

Kajuna, F.F., B.A. Temba, and R.D. Mosha. 2013. Surveillance of aflatoxin B1 contamination in chicken commercial feeds in Morogoro, Tanzania. Liv. Res. Rur. Dev. 25(3): 51.

Kanyi, K.J. 2018. Continental climate changes on the occurrence of aflatoxin producing Aspergillus species: Review. Austin Journal of Microbiology. 4(1): 1-4.

Kralik, G., Z. Kralik. M. Grčević, and D. Hanžek. 2018. Quality of Chicken Meat. In: Animal Husbandry and Nutrition. Banu Yucel \& Turgay Taskin (Eds). Intech. Pp. 63-94. 
Marangoni, F., G. Corsello, C. Cricelli, N. Ferrara, A. Ghiselli, L. Lucchin, and A. Poli. 2015. Role of poultry meat in a balanced diet aimed at maintaining health and wellbeing: an Italian consensus document. Food Nutr. Res. 59(1): 27606.

Marchioro, A.A., A.O. Mallmann, A. Diel, P. Dilkin, R.H. Rauber, F.J.H. Blazquez, M.G.A. Oliveira, and C.A. Mallmann. 2013. Effects of Aflatoxins on Performance and Exocrine Pancreas of Broiler Chickens. Avian Dis. 57(2): 280-284.

Missotten, J.A., J. Michiels, N. Dierick, A. Ovyn, A. Akbarian, and S. De Smet. 2013. Effect of fermented moist feed on performance, gut bacteria and gut histo-morphology in broilers. J. Br. Poult. Sci. 54(5):627-634.

Morrison, D., D. Ledoux, L. Chester, and C. Samuels. 2017. A limited survey of aflatoxins in poultry feed and feed ingredients in Guyana. Vet. Sci. 4(4): 17.

Mukandungutse, B.I., J.K. Tuitoek, A.M. King'ori, and M.A. Obonyo. 2019. The effect of fermentation with and without Saccharomyces cerevisiae on the levels of aflatoxin in maize. Liv. Res. Rur. Dev. 31(11): 172.

Naji, S.A., I.F.B. Al-Zamili, S.A. Hasan, and J.K.M. AlGharawi. 2016. The Effects of Fermented Feed on Broiler Production and Intestinal Morphology. Pertanika J. Tropic. Agric. Sci. 39(4): 597-607.

Negash, D. 2018. A review of aflatoxin: occurrence, prevention, and gaps in both food and feed safety. J. Nutr.Health Food Eng. 8(2): 190-197.

NRC (National Research Council). 1994. Nutrient Requirement of Poultry, $9^{\text {th }}$ Revised Edition, National Academy Press, Washington, DC.

Riovanto, R., M. De Marchi, M. Cassandro, and M. Penasa. 2012. Use of near infrared transmittance spectroscopy to predict fatty acid composition of chicken meat. Food Chem. 134(4): 2459-2464.
SAS Institute Inc, 2009. SAS/STAT User's guide: Statistics.

Sobrane, F.S.T., O.M. Junqueira, A.C.D. Laurentiz, R.D.S. Filardi, M.D.S. Rubio, K.F. Duarte, and R.D.S.D. Laurentiz. 2016. Effects of mycotoxin adsorbents in aflatoxin B1-and fumonisin B1contaminated broiler diet on performance and blood metabolite. Rev. Bras. Zootec. 45(5): 250256.

Sugiharto, S., C. Lauridsen, and B.B. Jensen. 2015. Gastrointestinal ecosystem and immunological responses in $\mathrm{E}$. coli challenged pigs after weaning fed liquid diets containing whey permeate fermented with different lactic acid bacteria. Anim. Feed Sci. Technol. 207: 278-282.

Sugiharto, S. and S. Ranjitkar. 2018. Recent advances in fermented feeds towards improved broiler chicken performance, gastrointestinal tract microecology and immune responses: A review. Animal Nutrition. 5(1): 1-10.

Syahidah, H.W., K. Selvaneswary, M. Normah, I.M. Syafiq, and D. Suhaimi. 2017. Survey on occurrence of aflatoxins in chicken feeds from Peninsular Malaysia. Malaysian Journal of Veterinary Research. 8(1): 103-112.

Valchev, I., V. Marutsova, I. Zarkov, A. Ganchev, and Y. Nikolov. 2017. Effects of aflatoxin B1 alone or co-administered with Mycotox NG on performance and humoral immunity of turkey broilers. BJVM. 20(1): 38-50.

Yunus, A.W., E. Razzazi-Fazeli, and J. Bohm. 2011. Aflatoxin B1 in affecting broiler's performance, immunity, and gastrointestinal tract: A review of history and contemporary issues. Toxins. 3(6): 566-590.

Zaki, M.M., S.A. El-Midany, H.M. Shaheen, and L. Rizzi. 2012. Mycotoxins in animals: Occurrence, effects, prevention and management. J. Toxicol. Environ. Health Sci. 4(1): 13-28. 